\title{
Characterisation of monzogranitic batholiths as a supply source for heritage construction in the northwest of Madrid
}

Rafael Fort, Monica Alvarez de Buergo, Elena Perez-Monserrat, Maria Jose Varas

Instituto de Geologia Economica (CSIC-UCM). Institute of Economic Geology, Spanish National Research Council, Complutense University of Madrid, Madrid, Spain

Departamento de Petrología. Facultad de Ciencias Geológicas. UCM. Department of Petrology, School of Geology, Complutense University of Madrid, Madrid, Spain

\begin{abstract}
The Church of the Assumption of Our Lady, in Valdemorillo (Madrid, Spain) is almost entirely built with granitoids. The studies and analyses were focused on the oldest part of the building (Ghosts Corner), which will be restored and rehabilitated in the near future. Homogeneous monzogranite is the predominant granitoid used in the Ghosts Corner, followed by granitic porphyry, porphyrytic monzogranite, gneiss and leucogranite. The original quarries that supplied homogeneous monzogranites for the first construction stages correspond to blocks present in the monument's surroundings. Quarries that supplied the granitic porphyries correspond to the dykes located to east-southeast of Valdemorillo, which are oriented $\mathrm{N}-\mathrm{S}$ in relation to their intrusion direction. The combined use of ultrasonic velocity and Schmidt hammer techniques allowed, first, selection of the most representative blocks and ashlars for sampling. This reduced sampling to a minimum, but yielded representative results for the whole building. Second, the combined values were used to compare results for the building stones of the church to rocks from the surrounding quarries. Stones from the building showed lower ultrasonic and Schmidt hammer values, and higher porosity and water saturation values compared to the original quarry rocks. The anisotropy indices are directly related to the decay processes in the stone: spalling of homogeneous monzogranite and grain disintegration in granitic porphyries.

Finally, the methods applied are inexpensive, easy to use and non-destructive techniques, very advisable properties when working with built heritage.
\end{abstract}

Keywords: Granites, Stone heritage, Ultrasonic velocity, Schmidt hammer, Weathering, Provenance quarries

\section{Introduction and aims}

The provenance of materials of which monuments are built is of significant interest not only from a historical point of view, but also in terms of the restoration and conservation of such monuments. Many examples of identification of the original quarries have recently been reported in the literature (Galán et al., 1999; Gomez-Heras and Fort, 2004; Dreesen and Dusar, 2004; Capedri and Venturelli, 2005; Carta et al., 2005; Nijland et al., 2006). Identifying such locations can lead to the use of, if not exactly the same, at least the most similar and compatible materials when replacement of highly decayed architectural elements is required. Comparative analysis of the properties of quarry materials and the corresponding lithotypes used in historical monuments offers useful parameters for evaluating the deterioration of building stones (Zezza, 1990). While working in outstanding examples of architectural heritage, it is common to find some historical documentation that indicates the use of a certain type of stone, and even the precise location of the original quarries (Galán et al., 1999; Dubelaar et al., 2006; Marini and Mossetti, 2006; Prikryl, 2006). Most of the time, it is necessary to assess and prove what is written in the stonemason's book. When dealing with less notorious examples of built heritage, previous clues may not be available, so samples from surrounding quarries may be required for comparison. The Church of The Assumption of Our Lady in Valdemorillo (Madrid, Spain) is the case study presented in this paper. This building is almost entirely built with granitoids. Madrid is currently the second most important region in Spain for granite extraction, with significance at an international level. The studies and analyses were focused on the Old Tower, which is the oldest part of the building, comprising mainly the tower itself and the sacristy. It is planned to restore and rehabilitate this section in the near future. 


\section{Geological setting}

Natural materials used for the construction of built heritage usually come from nearby areas. This is the main reason for studying the geology of the surrounding area for a case study of any building. Valdemorillo is located $40 \mathrm{~km}$ west of the city of Madrid (Fig. 1), at an altitude of 815 ma.s.l. Geologically, it is located in the southwestern area of the Guadarrama Mountain Range, which forms the northeastern section of the 500-km-long Spanish Central System, with the highest mountain being close to 2420 ma.s.l. This is mainly composed of Hercynian granitoids (344-285 Ma; Ibarrola et al., 1987) and highto medium-grade metamorphic rocks. Granitoids form the Guadarrama Batholith, consisting primarily of peraluminous monzogranites to leucogranites, with minor rocks of more basic composition (González-Casado et al., 1996). Post-Hercynian intrusive rocks are also common in the area, mainly in the form of dykes.

The geological setting on which the building is located presents a wide lithological variety (Fig. 2), with a predominance of granitic rocks, whichhave been quarried for construction purposes since ancient times, such as monzogranites, leucogranites, and gneisses (Spanish Geological Map series 1:50,000; ITGE, 1990; IGME, 2004). Monzogranites are the most abundant rocks, with differences in their texture, ranging from a non-porphyric (homogeneous monzogranite) to a porphyritic texture (porphyritic monzogranite) through a transitional contact. Monzogranites are hypidiomorphic, non-equigranular, with a medium to coarse grain size and present frequent subspheric, dark and micrograined xenoliths, ranging from tonalitic to quartzdioritic compositions. There are also dyke rocks intruding in the above-mentioned rocks: quartz (A-type), aplites (B-type), and granitic porphyries (C-type) dykes. Granitic porphyries are the most abundant dykes; these range in thickness from decimetres to tenths of a meter and are less than $3 \mathrm{~m}$ long, with clean/net contacts with the host rock. There are different emplacement/intrusion directions, and dykes can be distinguished according to their matrix texture. There are three major families of granitic porphyries dykes, one (C1-type) towards the east of Valdemorillo near the Aulencia River (Fig. 2) with a SW-NE orientation, with aphanitic matrix and gneiss intrusions. Two other families are to the north of the village, one near Santa LuciaHill (Fig. 2, C2 type)withaW-E orientation with a cryptocrystalline matrix, and the other with a N-S orientation (C3-type), with a micro to cryptocrystalline textured matrix; both intrude into homogeneous monzogranites. The largest phenocrysts are usually potassium feldspar crystals.

There are several abandoned quarries to the southwest of Valdemorillo (in both quartz A-type and porphyritic granite C-type dykes) and in Valdemorillo itself (formerly countryside areas, in monzogranite). In general, numerous quarries in metamorphic and granitic rocks for construction purposes (building and paving stones) have been the main economic activity in the area.

\section{The building}

3.1. Construction history

The Church of the Assumption of Our Lady (Fig. 3) is situated on a promontory within the urban centre. Its architecture shows different construction periods according to Rozadilla (1995) (Fig. 4). The beginning of its construction goes back to Visigothic or Mozarab times, when a church-probably a mosque-was founded in themiddle of the 8th century.

The remains of this original church are the first seven rough and rubble stone courses of the northern façade, which served as the support of subsequent extensions to the building. One of the first of these was the construction of the Old Tower (northwest angle of the building), which probably had a defensive role. The ground plan of the square tower was built in Romanesque style. Later on the tower may have belonged to the Templar Order (between 1128 and 1312), transformed 
first into a castle-convent, and later (13th century) into a bell-tower (Rozadilla, 1995). For this reason, themerlonswere removed, the upper windows were walled up and the entire construction was raised by building two windows in each façade to place the bells.

The monument has undergone significant modifications since 1312 , with the most significant works probably carried out during the 16th century (ashlar dated from 1521 in the southern façade of the church). The head of the church (both the Major Chapel and the Presbytery) is built over the foundations with very fine stonework (16th century).

Major repair works were carried out on the church (1592-1601) after a fire that took place in 1543; themain façade, the NewTower and the Baptistry Chapelwere built afterwards in the style of the brand new Monastery of El Escorial, as the same stonemasons worked in both buildings.

A Chapter Hall (Capitular RoomorMajor Sacristy) was built in 1676 to extend the original one, adjacent to the Old Tower (Fig. 4). At the end of these works, consecration took place in 1704, dedicating it to the Assumption of Our Lady. Fromthen to the end of the 20th century, there is no evidence of any other significant work on themonument. Cleaning and repointing of the stone masonry of the church were carried out in 1995. In 2003 the Heritage Conservation Group of the Institute of Economic Geology was contracted to study and analyse the Old Tower with a view to its restoration and rehabilitation.

Valdemorillo is on the so-called Imperial Route of the Region of Madrid, also known as the Route of San Lorenzo de El Escorial Royal Monastery.

\subsection{Building materials}

Each construction period of the church shows very important use of stonework, with a different stone-working method and distinctive stone use.

The church is built entirely of granitic building stones, with the minor presence of some quartz and gneiss blocks. The oldest part of the church, comprising the Old Tower, the Major Sacristy and the Mozarab Wall, seems to present a wider range of petrological varieties to the naked eye. The corner at which all these construction periods meet is known as the Ghosts Corner.

The Mozarab Wall is composed of poorly worked rubblework and quarry-faced masonry, of smaller size than that used in the Old Tower and Major Sacristy. Unworked quartz and gneiss fragments are used in theMajor Sacristy, corresponding to quarry-faced blocks and fragments that support larger size granitic blocks. The cornice ashlars of theMajor Sacristy are somewhat whiter, so they could have been set up during recent restorations. The building is in an acceptable conservation state, except for some dampness affecting the oldest section (Old Tower and Sacristy) (Fig. 5); this dampness, which mostly affects the first meter high of the building above the ground level (Fig. 5A), the corners (Fig. 5C) and the projected elements (Fig. 3C) is responsible for the biodeterioration processes, the deterioration of mortar joints (in many cases with a complete loss of themortar of the joints, which derived on some volume loss of the edges of the granite ashlars), as well as grain disintegration, scaling and spalling of the building stone (Fig. 5C). The dampness is a consequence of rainwater accumulation due to the lack of roof gutters and an incorrect paving slope to drain water (Fig. 3C).

\section{Methods}

Analyses andmeasurementswere carried out directly on the building stones of the church, limited to the northern and eastern façades of the Old Tower and Major Sacristy (on external and internal surfaces of the façade walls), and in the laboratory on samples and specimens taken from these areas. The same analyses and studies were performed on stones sampled from the surrounding quarries for comparison. Seven quarries were sampled: two from homogeneous monzogranites, three 
from granitic porphyries and two from porphyritic monzogranites.

Blocks of approximately $400 \mathrm{~mm}$ in size were extracted from quarries and then cut in the laboratory into prismatic specimens, measured, and then cut again into cubic specimens (50-mm side) and measured and tested again. Thin sections were prepared from fragments.

The procedures and techniques used for analysis are based on the principle that the physical and mechanical properties are a function of the mineralogical and textural characteristics of the rock (Tugrul and Zarif, 1999).

Surface mechanical properties were determined using an N-type Schmidt hammer (PROCEQ) to measure the surface hardness of the stones and obtain the Schmidt hammer value (SHV). Ultrasonic equipment (PUNDIT, C.N.S. Electronics, 54-MHz transducer) was used to measure the velocity of ultrasonic transmission.

The Schmidt hammer is widely used as an index test for quick characterisation of rock strength owing to its rapidity and ease of use, simplicity, portability, low cost and non-destructive nature (Yilmazand Sendir, 2002; Basu and Aydin, 2004). These authors reviewed a

wide range of studies to determine the usefulness of the Schmidt hammer test on different rock types. According to Karpuz and Pasamehmetoglu (1997), the test is very effective for determining the strength of weathered wall rock.

Both techniques provide a rapid and inexpensive measure of the surfacemechanical properties of rockmaterials (Aydin and Basu, 2005). Some authors consider that rock hardness is one of the most important parameters for determining rock properties for constructional purposes (Yasar and Erdogan, 2004; Yavuz et al., 2005), and also thatweathering significantly influences the engineering properties of rocks (Karpuz and Pasamehmetoglu, 1997). Schmidt hammer values in combination with ultrasonic velocity have been used for estimating the weathering rate and "physical state" of granites (Irfan and Dearman, 1978). Recent studies by Koca et al. (2006) have shown the utility of zoning maps obtained by Schmidt hammer test rebound values for initial assessment of overall condition of fire-exposed structural elements.

Two types of ultrasonic measurements were carried out: in situ measurements on the surface of the building's façades (indirect or surface method, Alvarez de Buergo and González, 1994), which avoids excessive sampling, and direct measurements on specimens in the laboratory (hereafter laboratory measurements in opposition to in situ ones). A total of 200 ashlars (120 on the external façades and 80 on the inside) were measured in situ in the church (most of them in the Old Tower, Major Sacristy and the primitive Mozarab or Visigothic church), aswell as granitic rocks fromfront quarries close to themonument. Five ultrasonic and Schmidt hammer measurements were carried out in the centre of each granitic ashlar (Fig. 6) and themean value was calculated. The distance between ultrasonic transducers was fixed to $150 \mathrm{~mm}$. Schmidt hammer testwere conductedwith the hammer held vertically downwards and at right angles to the horizontal rock surface.

The results obtained for granitic ashlars in the façades of the Old Tower and Sacristy allowed the identification of different types of granitic ashlars. Thus, representative sampling of the distinct granites could be carried out for petrological and petrophysical characterisation in the laboratory. Sample selection and definition of the sampling plan must be considered critical to the success of any provenance research (Beardsley and Goles, 2001). To minimise the sampling procedure, only specimens fromthe twomost representative lithological varieties in the building were sampled: two corresponding to granitic porphyry from the interior and exterior of Old Tower, and a third extracted from the exterior of the Old Tower froma homogeneousmonzogranite type. The specimenswere extracted frompoorly visible areas, the remaining void was filled and the external cover was restored using mortar that matched the stone.

The laboratory measurements were performed on granitic test specimens extracted from both the monument's façade and local 
quarries. First, specimensweremeasured along their entire length (after cutting the extremes in parallel), and then shorter specimens were cut andmeasured again. The anisotropy indiceswere determined according to Zezza (1990): total anisotropy index $\Delta M$, for which the three spatial directions are considered, and $\Delta \mathrm{m}$ or the relative anisotropy index, for which only two spatial directions are taken into account.

Petrographic analysis of the stones (thin sections from both the building and the surrounding quarries) was carried out by means of polarising optical microscopy (Axioscope, Zeiss).

Petrophysical characterisation involved determination of the apparent and bulk densities, water saturation (maximum water content a material may contain), open porosity (porosity accessible to water; RILEM, 1980), and chromatic parameters (Minolta CM 2002 spectrophotometer, L*a*b* system; CIELAB, 1976), as well as surface hardness by the Schmidt hammer and the ultrasonic velocity already described.

A petrologic study of the different types of rocks in outcrops and quarries in the vicinity of the monument was also carried out. Stone extraction fronts were located and sampled to compare these quarry samples to the materials used in the monument. The petrographic and petrophysical characteristics of these quarry rock materials and extraction front samples were determined. The methodology followed was the same as described for ashlars in the monument.

\section{Petrological characterisation}

The main lithological formations surrounding Valdemorillo, as previously described, are homogeneous monzogranite (Mh), on which the church is directly settled, porphyritic monzogranite (Mp), leucogranite (L), aplitic B-type dykes (dA), monzogranitic porphyritic C-type dykes (dP), quartz A-type dykes (Dq) and gneiss (G). It is likely that granitic rocks were taken from the areas surrounding the village. Even in the city centre, some abandoned quarries, albeit small, can be found. The quarries initially located near the centre of Valdemorillo are now within the city centre because of urbanisation due to the rapid increase in population, as reported for some other case studies (Koca and Kıncal, 2004). Different extraction methods can be observed, from direct working, cutting and carving of spheroidal weathered granitic blocks or boulders, to small exploitations, in some of which the upper level is only $20-25 \mathrm{~cm}$ thick, used to obtain small ashlars to supply local building stone (Fig. 7).

Table 1 lists the petrographic characteristics of the different types of granitoids, and Fig. 8 shows micrographs of the two main building granites obtained under the polarising microscope. Table 2 lists the percentage of each petrological type determined in three different areas of the building: the Old Tower (both inside and outside), the Major Sacristy and the Mozarab Wall. Homogeneous monzogranite is the predominant granitoid used in the building (70\%), followed by granitic porphyry $(15 \%)$, porphyrytic monzogranite $(11 \%)$, gneiss $(3 \%)$ and leucogranite $(1 \%)$.

\subsection{Comparison of quarry and monument values}

This section presents and discusses the results obtained for granitic rocks from both the monument and local quarries. The focus is on the most abundant rocks used in the monument: homogeneous monzogranites, porphyritic monzogranites and granitic porphyries.

Table 3 shows the chromatic parameters measured for homogeneous and porphyrytic monzogranites from local quarries and the monument. Results for the quarry andmonument rocks are very similar, especially those from internal areas of the building. No great difference between parameters measured in the exterior and interior is evident, which can be attributed to a cleaning operation carried out in 1995, after which no great soiling process has occurred.

Table 4 shows the real and bulk density values for the two most abundant granitic building stones used in the church: homogeneous 
monzogranite and granitic porphyry; no great differences are evident between the quarry and building stones.

Table 5 shows the ultrasonic velocity (in situ measurements, outside façades) and SHV results. Higher velocities, as well as higher SHV for homogeneous monzogranites and granitic porphyries, were measured in the quarry samples compared to the building stones. This reflects the fact that granitic ashlars show greater changes than granite from the quarry from which they originated.

Table 6 lists ultrasonic velocity results obtained by laboratory measurements performed on granitic test specimens taken from both the monument and local quarries. For granitic porphyries, the results differentiate the two main families of dykes of granitic porphyries found around Valdemorillo (C2 and C3-type), with different spatial intrusion directions and matrix textures. Northern dykes close to Santa Lucia Hill (C3-type) (Fig. 2) and east-west oriented dykes (C2-type) show lower values than those measured in building stones (rough stones of the Old Tower) from the monument. This implies that northern dykes (C2 and C3-type) were not used to supply material for construction of the Old Tower. Since their ultrasonic results fit much better to those measured for themonument, it is much more likely that south and southeast dykes (C1-type) supplied the stone. It is also possible that the stone came from outcrops in the very centre of the city that are no longer visible because they are under more recent constructions and buildings.

The anisotropy indices calculated (Table 6) indicate that homogeneous monzogranite is undergoing a degradation process that is similar

in the three spatial directions, which appears to be grain disintegration to the naked eye. In the case of porphyries, there is a decay process consisting of spalling, as indicated by the increase in total anisotropy index $\Delta \mathrm{M}(\%)$, while the relative anisotropy index $\Delta \mathrm{m}(\%)$ remains constant.

Finally, open porosity and water saturation were determined in the two more representative granites used as building stones in the church and compared with the provenance quarries (Table 7). The results show that porosity in the homogeneous monzogranites is higher in the monument than the quarry samples, indicating a decay process in the building stone (Old Tower and Major Sacristy), which increases the porosity. The low standard deviation $( \pm 0.23)$ indicates that the building stones measured are uniformly decayed. These properties were lower in samples of granitic porphyries from the building compared to those from selected quarries. Again, this is linked to the different granitic porphyries of the surrounding area, with matrix textures ranging from cryptocrystalline to microcrystalline and even aphanitic, which lead to wide data dispersion.

\section{Conclusions}

The Church of the Assumption of Our Lady in Valdemorillo, Madrid, was mostly built with monzogranite (homogeneous type). However, the most ancient section of the building, the Old Tower, the Major Sacristy and the Mozarab Wall (the Ghosts Corner), was built with a wider range of petrological varieties. Besides homogeneous monzogranite, granitic porphyry, porphyrytic monzogranite, gneiss and leucogranite were also found in this section. The Mozarab Wall is composed of poorly worked rubblework and quarry-faced masonry of smaller size than that used in the Old Tower and Major Sacristy. The first levels of the Old Tower and the Major Sacristy are mainly built with homogeneous and porphyritic monzogranites, as well as granitic porphyries to a lesser proportion. In the Major Sacristy, unworked quartz and gneiss fragments were also used, corresponding to quarryfaced blocks and fragments. This supports the premise that, the earlier the construction period, the poorer was the selection of materials available. It is most likely that rock fragments from the surrounding area were used at the very beginning of the church construction, as stone extraction techniques were very primitive, progressing in time. 
Homogeneous monzogranite is present in the highest part of the Old Tower, where the bells are set up, and in the Mozarab Wall, constructed for extension purposes.

The original quarries that supplied homogeneous monzogranites for the first construction stages correspond to blocks present in the monument's surroundings (spheroidal weathered granitic blocks and boulders, river fragments and pebbles), which are now inside the city centre, but were formerly on the outskirts of the small village that it used to be. Quarries that supplied the granitic porphyries correspond to the dykes located to east-southeast of Valdemorillo (C3-type dykes), which are oriented $\mathrm{N}-\mathrm{S}$ in relation to their intrusion direction. If stone needs to be replaced in the future, there are currently some active quarries in Valdemorillo for the extraction of porphyritic monzogranite. For homogeneous monzogranite, the nearest active quarries are a few kilometres to the northwest of Valdemorillo (the neighbour municipality of Zarzalejo).

Ultrasonic velocity and Schmidt hammer techniques were very useful in this study for several reasons. First, their combined use allowed selection of the most representative blocks and ashlars for sampling. This reduced sampling to a minimum, but yielded representative results for the whole building. Second, the combined values were used to compare results for the building stones of the church to rocks from the surrounding quarries. This represents a suitable approach for determining the original quarries that supplied stone for construction. The results also allowed the identification of changes in the building stones compared to intact or less altered rocks from the quarries. Stones from the building showed lower ultrasonic and Schmidt hammer values, and higher porosity and water saturation values compared to the original quarry rocks. The anisotropy indices are directly related to the decay processes in the stone: spalling of homogeneous monzogranite and grain disintegration in granitic porphyries. It should be noted that traditional petrological techniques and tests are still essential, especially polarising microscopy for final verification of the type of rock. Finally, the methods applied are inexpensive, easy to use and nondestructive techniques, very advisable properties when working with built heritage.

\section{Acknowledgements}

This study was financed by the Heritage General Directorate of Comunidad de Madrid (Regional Government of Madrid). The authors are also grateful to the MATERNAS programme (Durability and Conservation of Natural Traditional Materials for Architectural Heritage), which is also financed by Comunidad deMadrid (0505/MAT/94), to the CONSOLIDER programme (Technologies for the preservation and revalorisation of Cultural Heritage, CSD2007-0058) and to the Research Group financed by the Complutense University of Madrid "Alteration and Conservation of heritage stone materials (ref. 921349). The parish priest of Valdemorillo church is thanked for his helpful assistance.

\section{References}

Alvarez de Buergo, B.M., González, T., 1994. Estudio del método de la medida de la velocidad de propagación del sonido y su aplicación a edificios históricos. Ingeniería Civil 94, 69-74.

Aydin, A., Basu, A., 2005. The Schmidt hammer in rock material characterization. Engineering Geology 81, 1-14.

Basu, A., Aydin, A., 2004. A method for normalization of Schmidt hammer rebound values. International Journal of Rock Mechanics \& Mining Sciences 41, 1211-1214. Beardsley, F.R., Goles, G.G., 2001. Sampling for provenance: tailings from prehistoric stone quarries in the South Pacific. Journal of Archaeological Science 28, 587-595. Capedri, S., Venturelli, G., 2005. Provenance determination of trachytic lavas, employed as blocks in the Romanesque cathedral of Modena (Northern Italy), using magnetic susceptibility, and petrographic and chemical parameters. Journal of Cultural Heritage 6 (1), 7-19. 
Carta, L., Calcaterra, D., Cappelletti, P., Langella, A., de'Gennaro, M., 2005. The stone materials in the historical architecture of the ancient center of Sassari: distribution and state of conservation. Journal of Cultural Heritage 6 (3), 277-286.

Commission International de l'Eclaraige (CIE) CIELAB, 1976. Recommendations on uniform color spaces, color difference equations, psychometric color terms. CIE publication No. 15, Bureau Central de la CIE, Paris Colorimetry.

Dreesen, R., Dusar, M., 2004. Historical building stones in the province of Limburg (NE Belgium): role of petrography in provenance and durability assessment. Materials Characterization 53 (2-4), 273-287.

Dubelaar, C.W., Dusar, M., Dreesen, R., Felder, W.M., Nijland, T.G., 2006. Maastricht limestone: a regionally significant building stone in Belgium and The Netherlands. Extremely weak, yet time-resistant. In: Fort, Alvarez de Buergo, Gomez-Heras, Vazquez, Calvo (Eds.), Heritage,Weathering and Conservation, vol. 1. Taylor \& Francis Group, London, pp. 9-14.

Galán, E., Carretero, M.I., Mayoral, E., 1999. A methodology for locating the original quarries used for constructing historical buildings: application to Málaga Cathedral. Spain. Eng. Geol. 54, 287-298.

Gomez-Heras, M., Fort, R., 2004. Location of quarries of non-traditional stony materials in the architecture of Madrid: the crypt of Santa María la Real de la Almudena.

Materiales de Construccion 54 (274), 31-47.

González-Casado, J.M., Caballero, J.M., Casquet, C., Galindo, C., Tornos, F., 1996. Palaeostress and geotectonic interpretation of the Alpine Cycle onset in the Sierra del Guadarrama (eastern Iberian Central System), based on evidence fromepisyenites. Tectonophysics 262, 213-229.

Ibarrola, E., Villaseca, C., Vialette, Y., Fuster, J.M., Navidad, M., Peinado, M., Casquet, C., 1987. Dating of Hercynian granites in the Sierra de Guadarrama (Spanish Central System). In: Bea, Gonzalo, Lopez-Plaza, Rodriguez, Alonso (Eds.), Geologia de los Granitoides y rocas asociadas al Macizo Hesperico. Rueda, Madrid, pp. 377-383. Instituto Tecnológico y Geominero de España ITGE, 1990. Mapa Geológico de España 1:50000, San Lorezo de El Escorial 533, 18-21.

Instituto Geologico y Minero de España IGME, 2004. Mapa Geológico de España 1:50000, Majadahonda 558, 18-22.

Irfan, T.Y., Dearman, W.R., 1978. Engineering classification and index properties of a weathered granite. Bulletin of the International Association of Engineering Geology 17, 79-90.

Karpuz, C., Pasamehmetoglu, A.G., 1997. Field characterisation of weathered Ankara andesites. Engineering Geology 46, 1-17.

Koca,M.Y., Kıncal, C., 2004. Abandoned stone quarries in and around the Izmir city centre and their geo-environmental impacts, Turkey. Engineering Geology 75, 49-67.

Koca, M.Y., Ozdenb, G., Yavuzc, A.B., Kincala, C., Onargand, T., Kucuk, C., 2006. Changes in the engineering properties of marble in fire-exposed columns. International Journal of Rock Mechanics \& Mining Sciences 43, 520-530.

Marini, P., Mossetti, C., 2006. Natural stones used in a Royal House of Pedmont, Italy. In: Vazquez, Calvo (Ed.), In: Fort, Alvarez de Buergo, Gomez-Heras, Vazquez, Calvo (Eds.), Heritage, Weathering and Conservation, vol. 2. Taylor \& Francis Group, London, pp. 895-900.

Nijland, T.G., Dubelaar, C.W., Tolbbom, H.J., van Hees, R.P.J., 2006. Building stones from a muddy delta: native natural stone from The Netherlands. Extremely weak, yet time-resistant. In: Vazquez, Calvo (Ed.), In: Fort, Alvarez de Buergo, Gomez-Heras, Vazquez, Calvo (Eds.), Heritage, Weathering and Conservation, vol. 1. Taylor \& Francis Group, London, pp. 15-21.

Prikryl, R., 2006. New natural stone from the reconstruction of Charles Bridge in Prague. In: Vazquez, Calvo (Ed.), In: Fort, Alvarez de Buergo, Gomez-Heras, Vazquez, Calvo (Eds.), Heritage, Weathering and Conservation, vol. 1. Taylor \& Francis Group, London, pp. 23-29.

RILEM, 1980. Recommended tests to measure the deterioration of stone and to assess the effectiveness of treatment methods. Commission 25 PEM (Protection et erosion des monuments). Materials and Structures 75, 175-253.

Rozadilla, F., 1995. Valdemorillo y su Iglesia. Apuntes para una Historia. New Laser, S.L. Madrid.

Tugrul, A., Zarif, I.H., 1999. Correlation of mineralogical and textural characteristics with engineering properties of selected granitic rocks from Turkey. Engineering Geology 51, 303-317.

Yasar, E., Erdogan, Y., 2004. Estimation of rock physicomechanical properties using 
hardness methods. Engineering Geology 71, 281-288.

Yavuz, A.B., Turk, N., Koca, M.Y., 2005. Material properties of the Menderes Massif

Marbles from SW Turkey. Engineering Geology 82, 91-106.

Yilmaz, I., Sendir, H., 2002. Correlation of Schmidt hardness with unconfined compressive strength and Young's modulus in gypsum from Sivas (Turkey). Engineering Geology $66,211-219$.

Zezza, U., 1990. Physical-mechanical properties of quarry and building stones. Proceedings

of the Advanced Workshop "Analytical Methodologies for the Investigation of

Damaged Stones", Pavia (Italy), 14-21 September 1990.

\section{FIGURES AND TABLES CAPTIONS}

Fig. 1. Location map of Valdemorillo (Madrid, Spain).

Fig. 2. Geological scheme of the Valdemorillo area.

Fig. 3. Church of the Assumption of Our Lady. (A) General view of the church from the northeast outskirts of Valdemorillo, with some abandoned quarries-homogeneous

monzogranite- on the bottom right. (B) Studied section of the building: ot: Old Tower, ms: Major Sacristy, and mw: Mozarab wall. (C): Detail of the so-called Ghosts Corner.

Fig. 4. Building ground plan with the different constructive and architectural periods of the building, according to Rozadilla (1995).

Fig. 5. Detailed areas of the building in which the effect of dampness on the granite masonry is shown.

Fig. 6. Arrangement of the ultrasonic transducers on the surface of a granitic ashlar.

Fig. 7. Different methods used for extracting the granitic building materials. (A) Directly from spheroidal weathering granitic block. Some wedges marks can be observed in the middle of the block. (B) Small ashlars were extracted from the upper level bank. Both images correspond to homogeneous monzogranite.

Table 1. General petrographical characterization of the studied granites (from monument and quarries).

Table 2. Percentage of every petrological typology in different parts of the building.

Table 3. Chromatic parameters of the granitic stones from both the Monument (Old Tower) and quarry. L*: Luminosity / $a^{*}$ : chromatic coordinate (red-green hue) / b*: chromatic coordinate (yellow-blue hue) / YI: Yellow Index / WI: White Index.

Table 4. Densities of the granitic stones from both the Monument (Old Tower) and quarry.

Table 5. Ultrasonic velocity (in situ measurement) and Schmidt Hammer Values (SHV) in granites from quarry and monument.

Table 6. Ultrasonic velocity (laboratory measurements) and anisotropy indices of stones from both the Monument and quarry. a $\Delta M(\%)$ : Total anisotropy $=100[1-(2 Z / X+Y)]$, where $X, Y$ and $Z$ are the velocities measured in the 3 spatial directions. b $\Delta \mathrm{m}(\%)$ : Relative anisotropy $=100[2(X-Y) /(X+Y)]$, where $X, Y$ and $\mathrm{Z}$ are the velocities measured in the 3 spatial directions.

Table 7. Open porosity (n0 or porosity accessible to water) and water saturation in granitic stones from both Monument and quarry. 
FIGURES

Figure 1

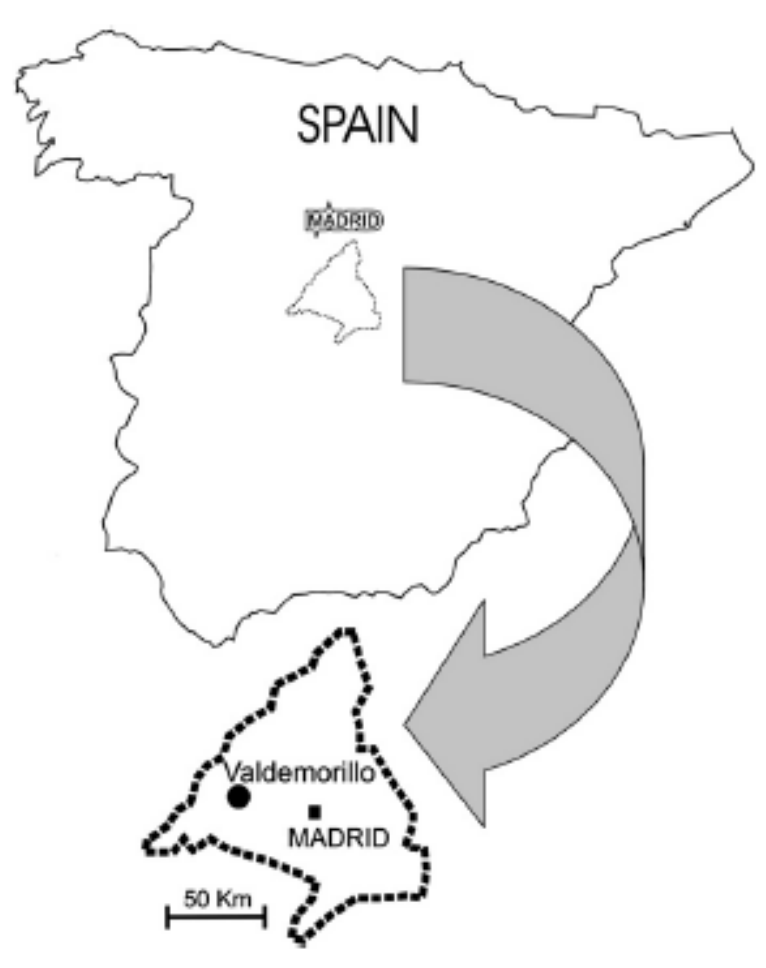


Figure 2

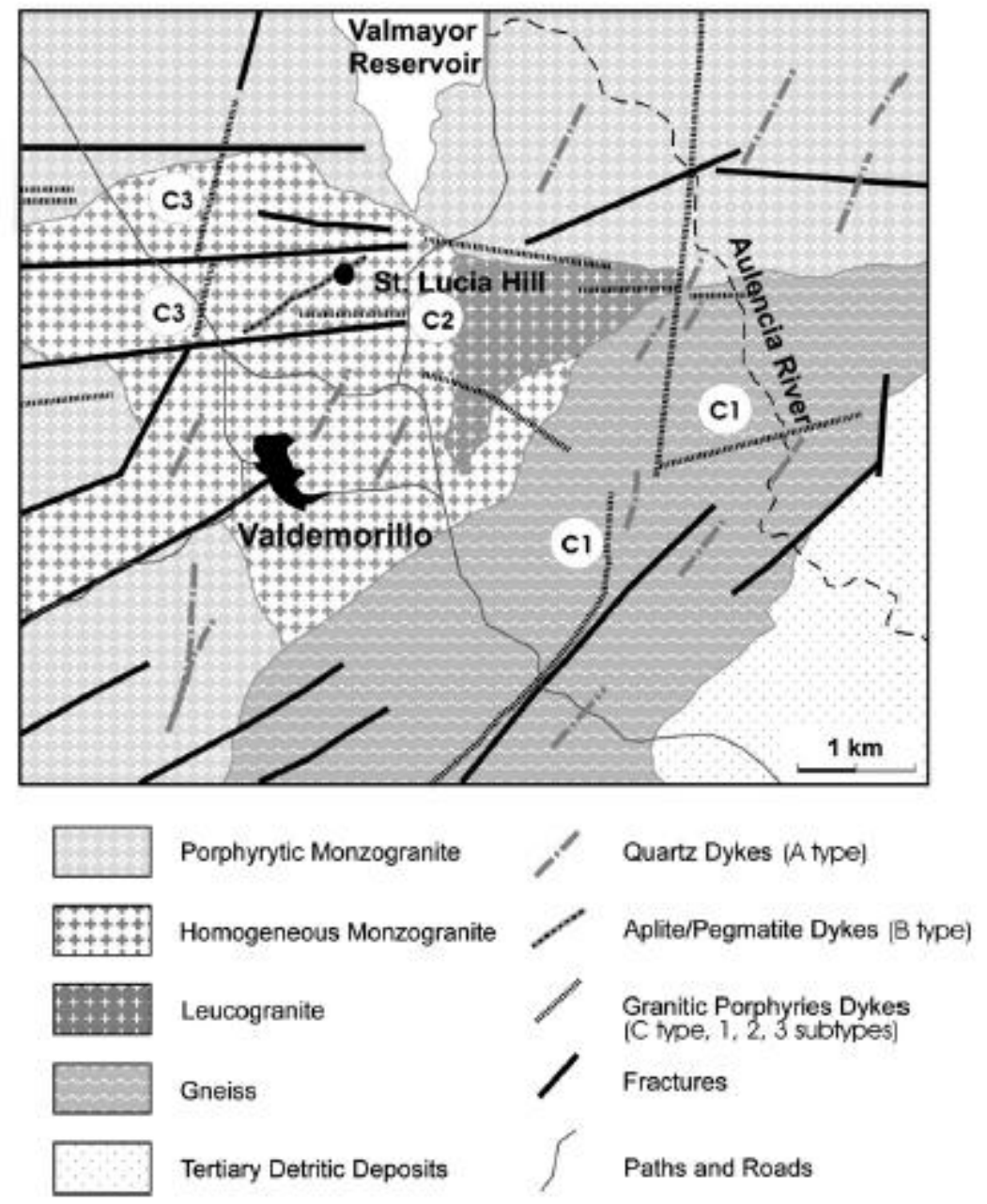


Figure 3

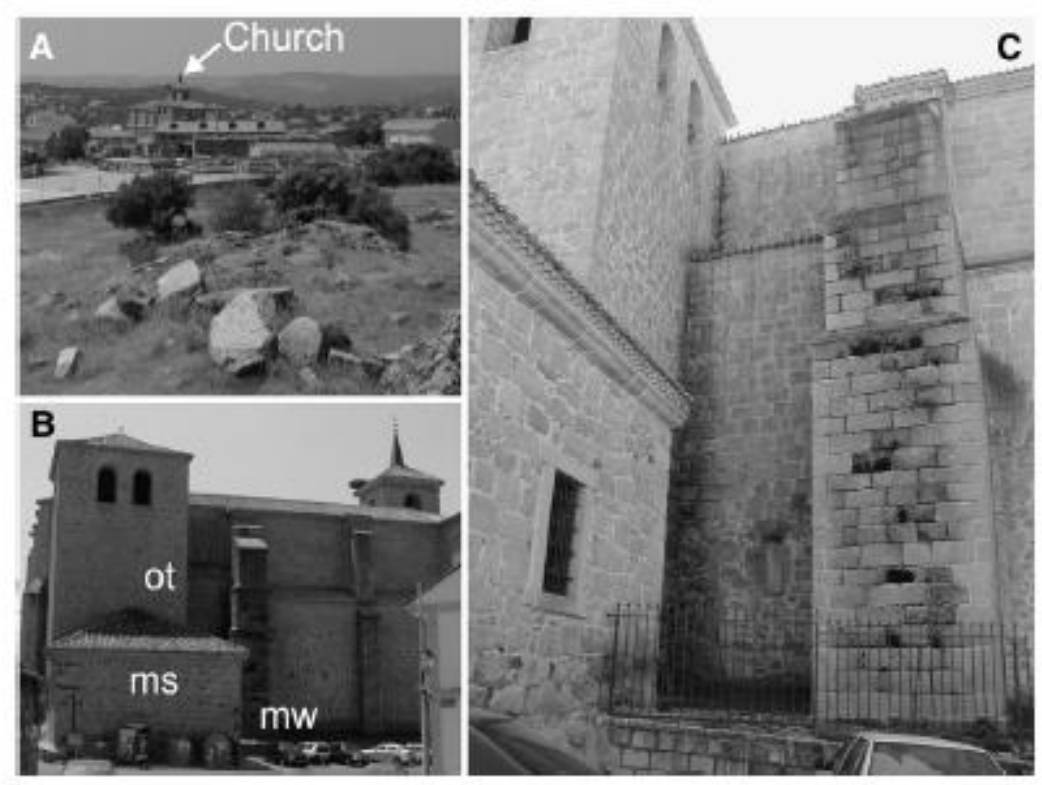


Figure 4

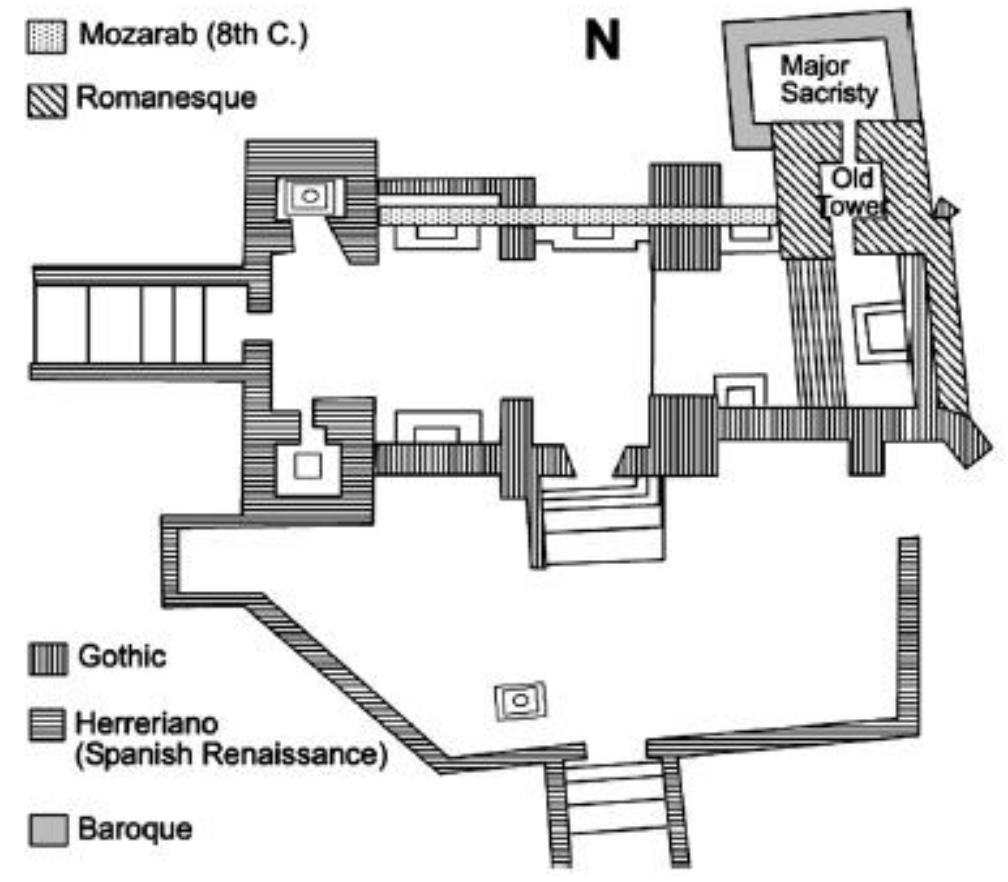


Figure 5

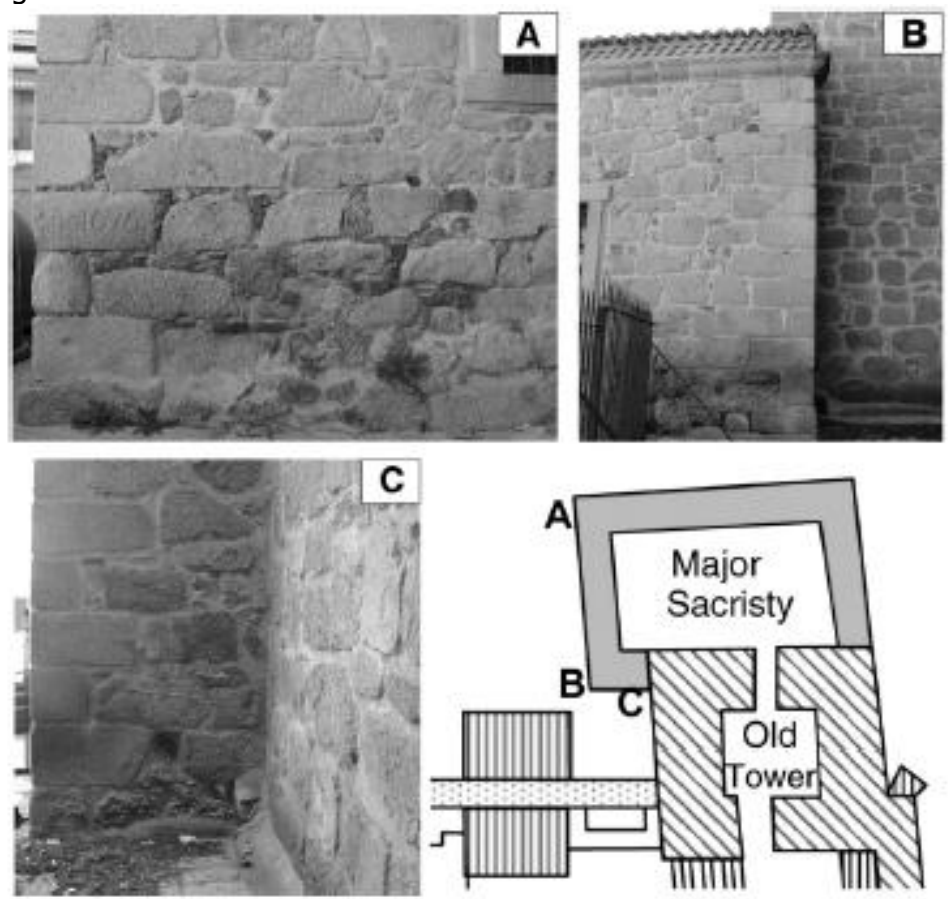


Figure 6

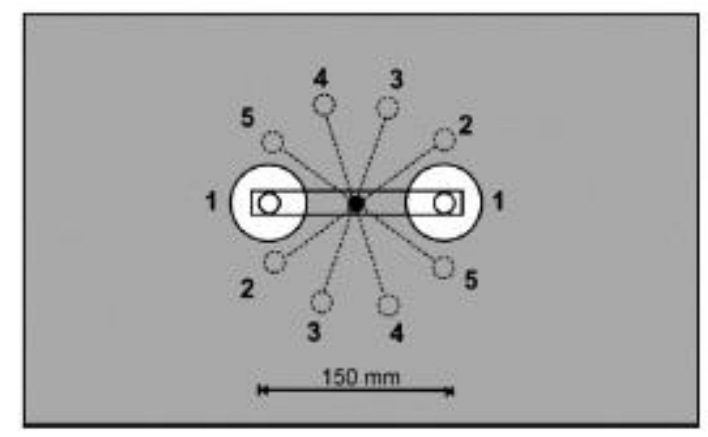


Figure 7

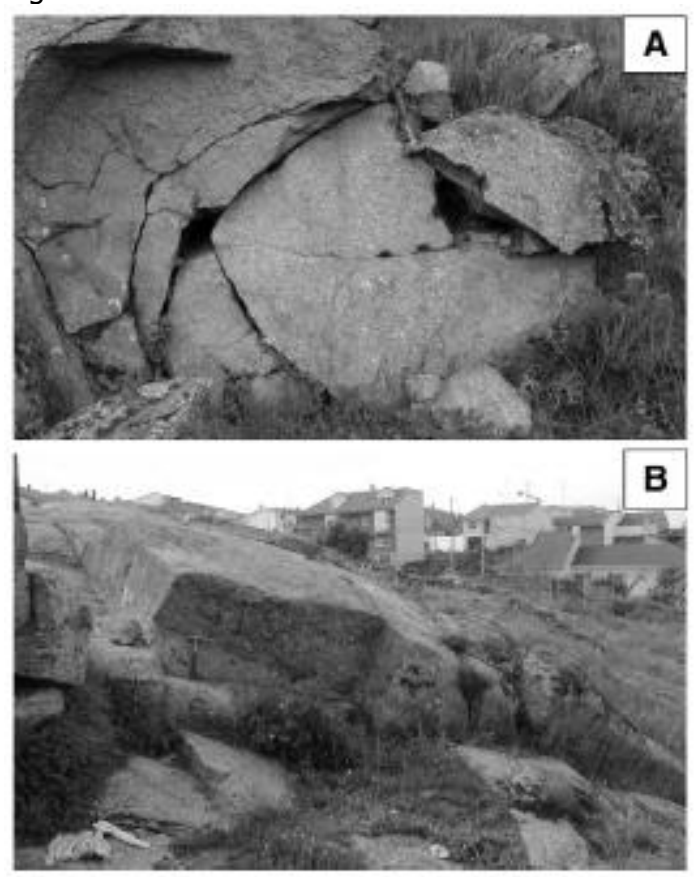


Figura 8

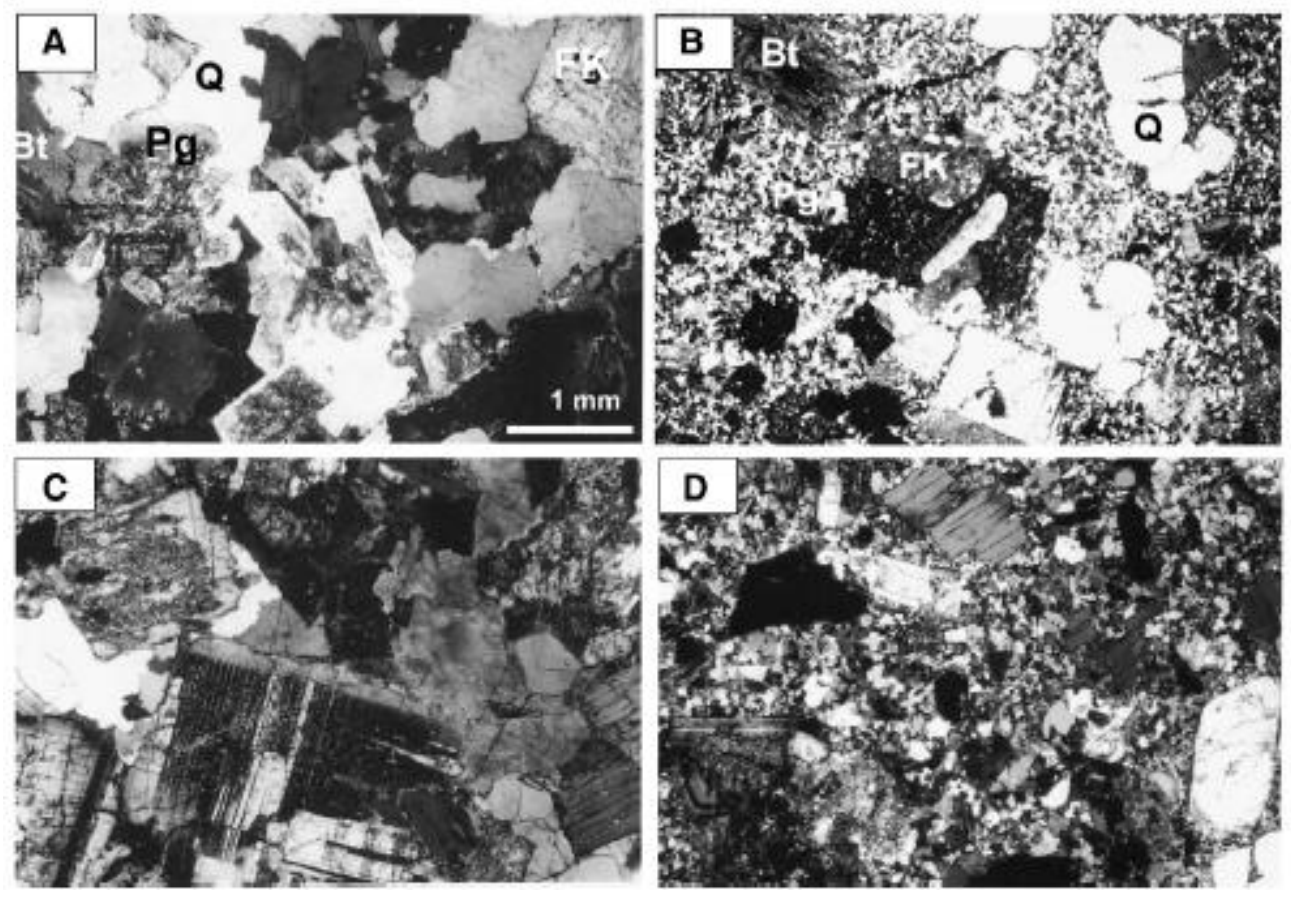


TABLES

Table 1

\begin{tabular}{|c|c|c|c|c|}
\hline & \multicolumn{2}{|l|}{ Homogeneous manxogranite } & \multicolumn{2}{|l|}{ Granitic porphyry } \\
\hline & Quarry & Churh & Quarry & Church \\
\hline $\begin{array}{l}\text { Texture } \\
\text { Primary mineraks }\end{array}$ & \multicolumn{2}{|c|}{ Quart, plygiodse (olgodsse), potasium feldspur (orthose) and biotie } & Inequigranul a porphyritic with a wide rang of phe & ocrystals size \\
\hline Secondary minerals & $\begin{array}{l}\text { Seridite, sphere, chloritz, prehnite, } \\
\text { muscovite, epidote, rutie }\end{array}$ & Chlariz, sericite & Chlarite, prehnite & \\
\hline Accessory mineals & Apatiz, zircon, opaques, ilmenite & & $\begin{array}{l}\text { Aputite, sircon, horblende, monxite, ferricarides, } \\
\text { ilmernite }\end{array}$ & Aputiz, epidor \\
\hline
\end{tabular}

Table 2

\begin{tabular}{|c|c|c|c|c|}
\hline \multirow[t]{2}{*}{ Petrologial variety } & \multicolumn{2}{|c|}{ Old Tower } & \multirow{2}{*}{$\frac{\text { Major }}{\text { Sucristy }}$} & \multirow{2}{*}{$\frac{\text { Maz:arab }}{\text { Wall }}$} \\
\hline & Inzeriar & $\overline{\text { Exterior }}$ & & \\
\hline Homogeneous morzogrmite & 71 & $\cos$ & 72 & 57 \\
\hline Porphyribic morzogranite & 13 & 9 & 10 & 14 \\
\hline Granitic parphysy & 16 & 23 & 10 & 21 \\
\hline leucogranite & 0 & 0 & 0 & 7 \\
\hline Gneiss & 0 & 0 & 8 & 0 \\
\hline
\end{tabular}

Table 3

\begin{tabular}{|c|c|c|c|c|c|c|c|}
\hline & & & $1^{*}$ & $a^{*}$ & $\mathrm{~b}^{*}$ & $\mathrm{n}$ & w! \\
\hline \multirow[t]{2}{*}{ Hamb gneous monnogranite } & Quarry & & $65.2 \pm 37$ & $0.17 \pm 0.8$ & $456 \pm 3.7$ & $9.43 \pm 7.7$ & $2223 \pm 120$ \\
\hline & Monument & $\begin{array}{l}\text { Ext } \\
\text { Int }\end{array}$ & $\begin{array}{l}63.6 \pm 90 \\
648 \pm 28\end{array}$ & $\begin{array}{l}21 \pm 1.1 \\
1.1 \pm 1.2\end{array}$ & $\begin{array}{l}7.1 \pm 1.5 \\
70 \pm 24\end{array}$ & $\begin{array}{l}152 \pm 25 \\
145 \pm 50\end{array}$ & $\begin{array}{l}13.3 \pm 6.3 \\
143 \pm 6.5\end{array}$ \\
\hline \multirow[t]{3}{*}{ Parphyrytic monnograniz } & Qurry & & $681 \pm 59$ & $-0.42 \pm 02$ & $216 \pm 13$ & $426 \pm 26$ & $3212 \pm 7.7$ \\
\hline & Monumert & Ext & $698 \pm 34$ & $a_{4} \pm a_{1}$ & $60 \pm 03$ & $11.9 \pm 08$ & $215 \pm 37$ \\
\hline & & Int & $71.7 \pm 34$ & $-a_{4} \pm a_{1}$ & $2 A \pm 0.4$ & $45 \pm 0.3$ & $356 \pm 38$ \\
\hline
\end{tabular}

Table 4

\begin{tabular}{|c|c|c|c|c|}
\hline & \multicolumn{2}{|l|}{ Quarry } & \multicolumn{2}{|l|}{ Monument } \\
\hline & $\begin{array}{l}\text { Real density } \\
\left(\mathrm{kg} \cdot \mathrm{cm}^{-2}\right)\end{array}$ & $\begin{array}{l}\text { Bulk density } \\
\left(\mathrm{kg} \cdot \mathrm{cm}^{-3}\right)\end{array}$ & $\begin{array}{l}\text { Real density } \\
\left(\mathrm{kg} \cdot \mathrm{cm}^{-2}\right)\end{array}$ & $\begin{array}{l}\text { Bulk dersity } \\
\left(\mathrm{kg} \cdot\left(\mathrm{cm}^{-2}\right)\right.\end{array}$ \\
\hline $\begin{array}{l}\text { Homogeneous } \\
\text { morkogranite }\end{array}$ & $2.664 \pm 3$ & $2601 \pm 7$ & $2653 \pm 1$ & $2573 \pm 3$ \\
\hline $\begin{array}{l}\text { Granitic } \\
\text { porhyry }\end{array}$ & $2607 \pm 4$ & $2547 \pm 5$ & $2675 \pm 0$ & $2620 \pm 1$ \\
\hline
\end{tabular}

Table 5

\begin{tabular}{|c|c|c|c|c|}
\hline & \multicolumn{2}{|l|}{ Quarry } & \multicolumn{2}{|l|}{ Monument } \\
\hline & $\begin{array}{l}\text { Ultrasanic vdodity } \\
\left(\mathrm{m} \cdot \mathrm{s}^{-1}\right)\end{array}$ & SHV & $\begin{array}{l}\text { Ultrsanic velocity } \\
\left(\mathrm{m} \cdot \mathrm{s}^{-1}\right)\end{array}$ & SHV \\
\hline $\begin{array}{l}\text { Homogeneous } \\
\text { morzogranite }\end{array}$ & $2514 \pm 637$ & $368 \pm 93$ & $1496 \pm 635$ & $26 \pm 81$ \\
\hline $\begin{array}{l}\text { Porphyritic } \\
\text { morzogranite }\end{array}$ & $2575 \pm 536$ & $337 \pm 99$ & $1930 \pm 557$ & $363 \pm 10$ \\
\hline $\begin{array}{l}\text { Granitic } \\
\text { parphyry }\end{array}$ & $2474 \pm 719$ & $41.7 \pm 9.6$ & $2342 \pm 1020$ & $37.5 \pm 1.8$ \\
\hline
\end{tabular}

Table 6

\begin{tabular}{|c|c|c|c|c|c|c|}
\hline & \multicolumn{3}{|l|}{ Quary } & \multicolumn{3}{|l|}{ Monument } \\
\hline & Ulrasanic vedocity $\left(\mathrm{m}^{-1} \mathrm{~s}^{-1}\right)$ & $\Delta \mathrm{M}^{2}(x)$ & $\overline{\Delta m^{b}(x)}$ & Ultrasonic vdodity $\left(\mathrm{m} \cdot \mathrm{s}^{-1}\right)$ & $\Delta M^{\top}(x)$ & $\overline{\Delta \mathrm{m}^{b}(x)}$ \\
\hline Hombgeneous manxpgranite & $4103 \pm 165$ & 19,4 & $1, A$ & $2296 \pm 105$ & 109 & 109 \\
\hline Granitic porphyry (N dykes $\mathrm{C} 2-\mathrm{C} 3$ type) & $2639 \pm 92$ & 120 & 15 & $3759 \pm 132$ & 13,2 & 3,8 \\
\hline Graritic porphyry (S-SE dykes, C1 type) & $5008 \pm 183$ & 5.2 & 36 & & & \\
\hline
\end{tabular}

Table 7

\begin{tabular}{|c|c|c|c|c|}
\hline & \multicolumn{2}{|l|}{ Quarry } & \multicolumn{2}{|l|}{ Monument } \\
\hline & Open poros ity $(x)$ & Water situration $(x)$ & Open parasity ( $(x)$ & Water suturition $(x)$ \\
\hline Hamogeneous man mogranite & $235 \pm 125$ & $0.91 \pm 0.52$ & $290 \pm 0.23$ & $1.20 \pm 0.09$ \\
\hline $\begin{array}{l}\text { Grantic porphyyy (N dyke, C2-C3-ype)" } \\
\text { Granitic porp hyry (E. dykes, C1-type) }\end{array}$ & $\begin{array}{l}5.25 \pm 0.65 \\
229 \pm 0.23\end{array}$ & $\begin{array}{l}211 \pm 0.28 \\
090 \pm 0.09\end{array}$ & $203 \pm 077$ & $a 77 \pm 029$ \\
\hline Granitic porphyry (S dykes)' & $360 \pm 1.61$ & $1.44 \pm 0.66$ & & \\
\hline
\end{tabular}

